WIDER Working Paper 2016/172

\title{
Fiscal decentralization and the shadow economy
}

Petr Janský and Miroslav Palanský*

December 2016

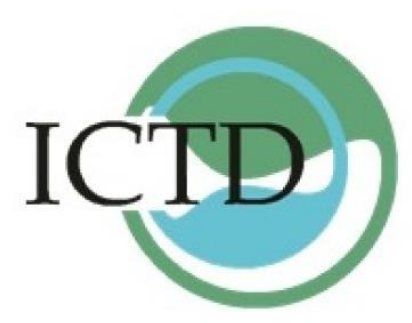

United Nations University World Institute for Development Economics Research 
Abstract: In this paper we use the new Government Revenue Dataset to analyse fiscal decentralization. We find that developed countries are on average more decentralized than developing countries and that Asia, Europe and North America are among the most fiscally decentralized regions. In our econometric analysis, we examine the relationship between fiscal decentralization and the shadow economy. We hypothesize that decentralization can negatively or positively affect the size of the shadow economy, increasing or decreasing its size, and that this effect can vary according to a country's level of development. We first replicate earlier results of cross-country analysis and proceed by estimating a fixed effects model, which provides evidence of a relatively robust and statistically significant relationship between tax revenue decentralization and the size of the shadow economy. We find that in developing countries a higher level of decentralization is associated with an increase in the size of the shadow economy, while in developed countries the opposite effect prevails.

Keywords: taxation, decentralization, fiscal decentralization, shadow economy, developing countries.

JEL classification: $\mathrm{H} 20, \mathrm{H} 71, \mathrm{H} 72, \mathrm{O} 17$

Acknowledgements: The authors gratefully acknowledge the support of UNU-WIDER.

\footnotetext{
* Both authors: Institute of Economic Studies, Charles University, Prague, Czech Republic; corresponding author: miroslav.palansky@fsv.cuni.cz.
}

This study is an outcome of the Symposium on Taxation and Revenue Mobilization in Developing Countries organized by the International Centre for Taxation and Development (ICTD) and the United Nations University World Institute for Development Economics Research (UNU-WIDER). It is part of UNU-WIDER's research project on 'Macro-Economic Management (M-EM)'.

Copyright (C) UNU-WIDER 2016

Information and requests: publications@wider.unu.edu

ISSN 1798-7237 ISBN 978-92-9256-216-8

Typescript prepared by Sandra Rawlin.

The United Nations University World Institute for Development Economics Research provides economic analysis and policy advice with the aim of promoting sustainable and equitable development. The Institute began operations in 1985 in Helsinki, Finland, as the first research and training centre of the United Nations University. Today it is a unique blend of think tank, research institute, and UN agency — providing a range of services from policy advice to governments as well as freely available original research.

The Institute is funded through income from an endowment fund with additional contributions to its work programme from Denmark, Finland, Sweden, and the United Kingdom.

Katajanokanlaituri 6 B, 00160 Helsinki, Finland

The views expressed in this paper are those of the author(s), and do not necessarily reflect the views of the Institute or the United Nations University, nor the programme/project donors. 
Fiscal decentralization is an important economic and political phenomenon as well as an integral part of revenue mobilization in developing countries. Using the new Government Revenue Dataset (GRD), we begin our empirical research in this paper by observing fiscal decentralization over time and in a number of developing countries. We then proceed to study the relationship between fiscal decentralization and the size of the shadow economy using the best available data for both these phenomena. Determining the channels through which decentralization affects the size of the shadow economy is an important concern for policy makers so that, for example, they can improve tax collection by pinpointing the optimal level and type of decentralization.

Our particular focus is on fiscal decentralization in developing countries. Based on theoretical considerations, which we present in the following section, we hypothesize that the effect of fiscal decentralization on the size of the shadow economy may be different for developing and developed countries. We use the GRD data, which provides particularly broad coverage for tax revenues of developing countries, and complement this with Government Finance Statistics (GFS) data and three sources of shadow economy estimates, that together cover most countries of the world. Using descriptive statistics, we highlight interesting observations about the level of revenue decentralization in both developing and developed countries. In our econometric analysis, we examine the situation in developing countries specifically and consider whether the relationship between the two variables is different for these countries.

Overall, we believe that our research makes at least three novel contributions. As far as we know, we are the first to use the GRD data to study fiscal decentralization. Second, we merge the GRD data with the International Monetary Fund's (IMF's) GFS data. This enables us to compare the two data sources, but also to use expenditure-based indicators of fiscal decentralization from the GFS, since the GRD contains only revenue-related information. Third, we empirically examine the relationship between fiscal decentralization and the size of the shadow economy, and are the first to do so with panel data and with multiple sources of shadow economy estimates.

The remainder of this paper is structured as follows. In the following section, we review the literature on fiscal decentralization and shadow economies. We proceed to describe the data sources used in the analysis, before presenting the summary statistics for fiscal decentralization in various countries over the years, focusing on developing countries. Finally, we present and interpret the econometric results of our analysis of the relationship between fiscal decentralization and shadow economies.

\section{$2 \quad$ Literature review}

The existing literature related to our research is quite voluminous and there are a number of both research and policy papers relevant to fiscal decentralization and the shadow economy. We classify the existing literature into two main categories. First, we discuss literature concerning fiscal decentralization, especially work that focuses on developing countries. Second, we review the literature on the shadow economy and its relationship with fiscal decentralization.

\subsection{Fiscal decentralization}

The general theory of fiscal decentralization began to develop in the 1950s following Samuelson (1954) and Musgrave (1956), who elaborated on the nature of public goods and expenditure 
structure. The first-generation theory recognized the main benefits and drawbacks of intragovernmental transactions as well as the decentralized approach. Based on a series of simple premises, it suggested that local government is best informed about local preferences and thus can allocate public resources most effectively (Tiebout 1956). This effect is more palpable the more geographically heterogeneous the country is, since in more heterogeneous countries citizens in different parts of the country tend to have more diverse preferences, which makes policies implemented at the national level less effective. Local governments' raison d'être is therefore to provide public goods whose consumption is limited to their own jurisdiction (Oates 1999). On the other hand, according to the first-generation theory, central governments should provide a means of maintaining macroeconomic stability and obtaining national public goods, and should be responsible for monitoring policies implemented at the local level, correcting for possible negative spill-overs to other local units.

Another important means by which fiscal decentralization can improve a country's economic performance is by stimulating competition among the local governments (Rodríguez-Pose and Ezcurra 2011). When citizens are able to 'vote with their feet', i.e. are able to choose to move to a locality based on their preferences, local governments have to keep up with this competition. This in turn reduces the risks of corruption and rent-seeking practices, while stimulating innovation in providing public goods (Tiebout 1956; Breton 1998; Donahue 1997). Closer proximity between citizens and their elected officials also increases transparency and participation in policymaking, which reduces transaction costs (Putnam et al. 1994; Rodríguez-Pose and Ezcurra 2011).

Some strands of literature, however, have also emphasized the risks of fiscal decentralization. First, as pointed out by Rodríguez-Pose and Gill (2005), the need of certain public goods is identifiable at the national level. This includes basic needs such as access to food, education, safety, health care, or basic infrastructure. Taking advantage of economies of scale, central governments may be better suited to provide these goods efficiently. Second, when central governments increase local units' autonomy by giving them the right to decide about their expenditures, while committing to finance them, the local governments may over-spend, which would lead to an inefficient use of public resources (Rodríguez-Pose and Gill 2005). This problem may be minimized by making the local governments bear the responsibility for any debt they create (Inman 2003). Nevertheless, especially in developing countries, enforcing such responsibilities may be difficult. Third, as Storper (2005) explains, local units may be more likely to be captured by special-interest groups because of lower public control at the local level. Fourth, poorer local units may be less effective in providing public goods or in taxation due to a lack of expertise and human resources (Prud'Homme 1995); again, an effect likely to be more pronounced in less developed countries.

Interesting developments have occurred in transition countries, where some type of sub-national government structure existed even under the socialist regime, but policymaking was made entirely at the central and national level. Local governments acted only as branch offices of the central bureaucracy with little to no financial autonomy (Bird et al. 1998). For most transition countries, decentralization was one of the top priorities after the liberalization of their markets, along with privatization. The decentralization process and its success have differed significantly across countries. This is not only due to historical, political, ethnic, geographic, and demographic differences, but also to different approaches to decentralization. As mentioned in Dabla-Norris (2006), the pioneers among the transition countries in Central and Eastern Europe in terms of reforms in legal and institutional framework were Poland, Hungary, and the Czech Republic. By contrast in Bulgaria, as late as in 1999, local governments were responsible for carrying out expenditures, but about 90 per cent of these expenditures were defined by law and thus were not under the local governments' control (McCullough et al. 2000). Hungary also encountered inefficiencies due to small municipalities' inability to provide a sufficiently broad range of services (Wetzel and Papp, 2003). It is thus clearly very important to identify the most efficient size for 
local government units. Meanwhile, countries such as the Kyrgyz Republic and Tajikistan have taken much longer to prepare their institutions for decentralization.

\subsection{Fiscal decentralization and the shadow economy}

The substantial extent of shadow economic activities is of great concern to all policymakers, especially in developing countries. Estimates of the shadow economy's size vary significantly across countries, from around 9 per cent of GDP for developed countries such as Austria and the USA to approximately 60 per cent of GDP for countries such as Georgia, Zimbabwe, or Bolivia (Elgin and Oztunali 2012). As Tafenau et al. (2010) point out, this has recently led to problematic situations in the Southern European countries: Greece, Spain, and Italy all have relatively large shadow economies, and as a consequence their governments do not have enough fiscal capacity to maintain balanced budgets in times of crises. Policymakers address shadow economies using a number of approaches: these can include improving law enforcement and punishment, reforming and simplifying tax systems and regulatory instruments, and enhancing the efficiency of public services. This paper aims to study the effects of a phenomenon only little explored in this context so far: decentralization.

Several theoretical hypotheses have been proposed that focus on the possible effects of decentralization on the size of the shadow economy. The earliest theories of decentralization (reviewed above) suggested that local governments were best informed about local preferences and thus best suited to allocate public resources effectively. Efficient public spending may in turn lead to fewer people and firms turning to shadow economy practices. However, some researchers have emphasized the disadvantages that fiscal decentralization can bring, most of which are connected to a potential lack of expertise and human resources at the local level to carry out policies effectively. Overall, the existing literature suggests that decentralization can have both positive and negative effects on the size of the shadow economy.

Buehn et al. (2013) list two main ways in which decentralization could decrease the extent to which people tend to hide their economic activity from the state. Firstly, as Tiebout (1956) sketched out, decentralization can provide a more effective and transparent way of spending public resources, thereby promoting the willingness to pay taxes, which may in turn lead to enhanced economic growth. Secondly, decentralization can provide greater transparency and more insight into how resources are spent, decreasing the shadow economy through better government oversight. While Torgler et al. (2010) and Teobaldelli (2011) suggest that this effect might prevail, the data used in their analyses are limited. We aim to build on and improve their research by using better data sources as well as a more general methodology.

On the other hand, we identify in the literature three ways in which decentralization may increase the size of the shadow economy. First, as Storper (2005) explains, local units may be more likely to be captured by special-interest groups, due to potentially lower public control at the local level (i.e. local level expenses may become too small for effective control to pay off). Second, poorer local units may be less effective in providing public goods due to a lack of relevant expertise and human resources (Prud'Homme 1995). Third, decentralization can lead to variations in administrative and legislative requirements for businesses across regions, increasing the chances that these requirements become less transparent and are no longer simple enough for people to understand. These negative effects of decentralization are likely to be more pronounced in developing and transition countries, especially as local government employees are often insufficiently trained to undertake newly assigned tasks.

We investigate the effect of decentralization on the share of shadow economic activities by estimating a regression model with a number of control variables, following and extending the 
approach taken by Buehn et al. (2013). Furthermore, we improve on their results by using relatively newly available data on both fiscal decentralization and the size of the shadow economy in individual countries. Specifically, we create a panel dataset to estimate a fixed effects model. As a result, we obtain the best possible estimates of the relationship between decentralization and the size of the shadow economy.

\section{Data}

In our empirical analysis, we use data that can be classified into three categories - decentralization measures (fiscal and political), size estimates for the shadow economy, and control variables used in the analysis of the relationship of the two. The definitions of these categories and a summary of the used variables are available in Tables A1 and A2 in the Appendix, respectively.

\subsection{Fiscal decentralization}

The first group of decentralization measures is based on the GRD dataset created with the support of the International Centre for Tax and Development, which contains data on various types of government revenues at both central and general levels. It was prepared with a special emphasis on developing countries, and was recently introduced by Prichard et al. (2014). We downloaded it from the ICTD website on July 7, 2016. ${ }^{1}$

We complement the GRD with the IMF's GFS, which we accessed through the IMF eLibrary Data. ${ }^{2}$ While the GFS covers all expenditures and revenues at all levels of government, the GRD dataset focuses only on revenue data for central and general government levels, but is more voluminous - in particular for some developing countries - and is of higher quality, since it uses government revenue data from multiple sources. ${ }^{3}$ As the IMF itself acknowledges in a recent helpful paper by Seiferling (2013), the complexity of the GFS database makes it difficult and tedious to work with; despite some improvements, there is still a long way to go before it will be user-friendly. Nevertheless, it provides uniquely detailed and varying coverage across countries and years that has only recently been rivalled by the GRD.

Using our merged dataset, we construct two variables for fiscal decentralization - one on the income $(r e v D e c)$ and one on the expenditure side $(\operatorname{expDec})$, both following the approach taken by Dziobek et al. (2011). We start by constructing variables that represent the ratio between central and general government revenues and expenditures (GL2/GL3). To transform these variables into measures of decentralization rather than centralization, we use the following formulas:

\footnotetext{
1 Available at: http://www.ictd.ac/en/about-ictd-government-revenue-dataset.

2 Available at http:/ / elibrarydata.imf.org/. The GFS dataset consists of data downloaded in two periods. First, data before the year 2010 were downloaded on August 18, 2013. Second, data for the years 2010-2013 were downloaded on November 8, 2014 and were appended to the original file. On both occasions, thanks to a free trial, we created a number of download queries encompassing all the relevant information, before merging these to obtain the best freely available dataset with the GFS data.

${ }^{3}$ We also considered using some other sources on government expenditures, either as substitutes or complements for the GFS, but decided not to in the end because they seemed substantially inferior to the sources used by the GFS. E.g. Government Spending Watch (http://www.governmentspendingwatch.org) seemed a useful source of data at first glance, however initial analysis revealed that these data are partial and the sources for each individual item are not clearly identified. Furthermore, the format in which the data are provided online is not user friendly and it would take longer than normally required to prepare them for inclusion in our dataset.
} 


$$
\begin{aligned}
& \text { revDec }=\left(1-\frac{T_{C L}}{T_{T O T}}\right) * 100 \\
& \text { expDec }=\left(1-\frac{E_{C L}}{E_{T O T}}\right) * 100
\end{aligned}
$$

where $T_{C L}$ are taxes collected at the central government level, $T_{T O T}$ are total taxes collected by the government (at all levels), $E_{C L}$ are government expenditures at the central government level, and $E_{T O T}$ are total government expenditures (at all levels). These measures thus represent the percentage of total government revenues and expenditures carried out at lower-than-central (subnational) levels of government. The higher the measures revDec and $\operatorname{expDec}$ are, the more decentralized the country is in terms of fiscal revenues and expenditures, respectively. In other words, if a country collects all its tax revenue at the central level of government, the variable revDec will take the value 0 .

Our third measure of fiscal decentralization focuses on the concentration of employee compensation at the central level of government and thus represents an additional measure of fiscal decentralization expenditure (emplDec). It is defined as:

$$
\text { emplDec }=\left(1-\frac{E C_{C L}}{E C_{T O T}}\right) * 100
$$

where $E C_{C L}$ is government employee compensation at the central government level, and $E C_{T O T}$ is total government employee compensation (at all levels). The higher this number, the more decentralized the country is in terms of its employee cost distribution. If a large share of government workers are employed at regional or municipal levels, the distribution of administrative and decision-making power is more decentralized throughout the country. From a psychological point of view, this type of measure of decentralization may be relevant in terms of public officers' accountability and the government's proximity to the people.

\subsection{Political decentralization}

The second group of decentralization measures focuses on the political dimension. We use three variables in this group, all of which are based on Fan et al. (2009). A general disadvantage of this dataset lies in its lack of time dimension. As a consequence, these measures of political decentralization can only be used in a cross-sectional analysis. On the other hand, data on these measures are available for a wide range of countries.

The first measure of political decentralization is the number of government tiers (tiersDec). For 156 countries, Fan et al. (2009) calculated the number of levels at which a state executive body existed 'which met three conditions: (1) it was funded from the public budget, (2) it had the authority to administer a range of public services, and (3) it had a territorial jurisdiction.' The variable takes values between 1 (most centralized countries) and 6 (most decentralized countries).

The second measure of political decentralization is the average number of people living within the jurisdiction of each lowest-level government unit (bottomUnitSizeDec). This is calculated by dividing the number of lowest-tier government units by the total population. We obtained data on the number of lowest-tier government units from Fan et al. (2009) and population data from the World Bank. We consider this variable to be a measure of the lowest level of government's 
proximity to the people. A smaller number of inhabitants per lowest-tier government unit indicates a more politically decentralized system of government. ${ }^{4}$

Our last measure of decentralization is connected to the low-tier public officers' accountability (lowUnitElDec). It is a composite variable created as the sum of the variables BTE (bottom tier elections) and SLTE (second-lowest tier elections) from Fan et al. (2009). Each of these takes the value 1 if the public officers at the lowest or second-lowest government level, respectively, are elected directly or chosen by a directly elected local assembly, and zero if these officers are appointed by higher level officers. They take the value 0.5 if some executives are appointed while others are elected. The higher this number is, the more low-level public officers are elected directly and thus the greater their accountability is with respect to the electorate.

\subsection{Shadow economy}

We use three sets of estimates to quantify the sizes of shadow economies. By using the results of a wide range of studies, we aim to improve the robustness of using these very rough estimates of a phenomenon that is intrinsically difficult to quantify. The principal dataset on the size of shadow economies used in our analysis is the one created by Elgin and Oztunali (2012), which relies on a simple deterministic dynamic general equilibrium model calibrated using data estimated by Schneider et al. (2010). This dataset can be considered the most extensive and accurate dataset in the literature as it extends the previously used methodology. Bittencourt et al. (2014), Goel and Saunoris (2014), and Pappa et al. (2015) have all recently used these estimates in their empirical studies. We also check the robustness of our results using other established estimates of shadow economies on smaller samples, specifically those presented by Alm and Embaye (2013) and Schneider et al. (2010).

Alm and Embaye (2013) estimate the size of the shadow economy for a panel of 111 countries over the time period 1984-2006. Their methodology relies on the currency demand method and the GMM dynamic panel data model. Unlike previous literature, the authors include a measure of tax administration enforcement strength as a key factor determining the extent of tax evasion. On the other hand, this approach lacks micro-foundations, as the model does not include a measure of individual workers' motivation to bypass the formal economy.

Schneider et al. (2010), whose data are used by Elgin and Oztunali (2012) to calibrate their model's parameters, present estimates of the volume of shadow economic activities for an unbalanced panel of 162 countries for a period of up to 9 years from 1999. The estimates are derived from a Multiple Indicators Multiple Causes model, a structural equation model that uses a set of observed variables to compare its covariance matrix with the parametric structure imposed on it by a hypothesized model (Schneider et al. 2010). The size of the shadow economy is the unobserved variable, whereas a number of explanatory variables (which serve both as causes and indicators of the shadow economy) are used to identify the relationships between these and the unobserved variable. Finally, the estimated sizes of the shadow economy are converted into percentages of official GDP using a calibration technique popularized by Dell'Anno (2007).

It is important to keep in mind that determining the size of the shadow economy precisely is, by definition, impossible. However, using advanced econometric techniques and a number of observable variables, we can obtain relatively robust estimates of the volume of informal economic

\footnotetext{
${ }^{4}$ Please note that this variable is, strictly speaking, a measure of centralization. Therefore, the higher this number, the more centralized the country is. For purely technical reasons only, it is difficult to correspondingly transform this variable into a measure of decentralization similar to the others used in the analysis.
} 
activities in most countries. Using structural equation models and the Multiple Indicator Multiple Causes (MIMIC) approach seems rigorous; however, this method has also its drawbacks, in particular the necessity of deciding ad hoc which causes and indicators to include in the model (Dreher and Schneider 2010). Despite these caveats, estimating the size of the shadow economy and determining its drivers can provide a useful tool for economists and policy makers.

As control variables, we use measures that are generally considered to affect the size of the shadow economy. Previous empirical studies suggested relationships between the size of the shadow economy and a number of characteristics. In our models, we include GDP per capita (in thousands of US dollars) (Feld and Schneider 2010), which is expected to have a negative sign (i.e. higher GDP per capita is associated with lower volumes of shadow economic activities); unemployment rate (Dell'Anno and Solomon 2008) with an expected positive sign; institutional quality (Torgler et al. 2010) measured as the mean of three World Governance Indicators ${ }^{5}$ (government effectiveness, rule of law and control of corruption) following Buehn et al. (2013), whose coefficient is expected to have a negative sign; and tax burden (Johnson et al. 1998a, 1998b; Schneider et al. 2010) with an expected positive sign (higher imposed taxes are expected to be associated with a larger shadow economy). We then merge these data sources into a panel dataset, which contains the best available data on both fiscal and political decentralization, the size of the shadow economy and the control variables used in the regressions.

\section{$4 \quad$ Descriptive statistics}

In this section, we explore the merged dataset using summary statistics and describe the principal advantages of our dataset in the study of fiscal decentralization. An illustration of the improved availability of data achieved by using the GRD rather than the GFS dataset is presented in Figure 1. For an illustrative case of Georgia, the GFS dataset contains data for the years 2003-2012. The availability of the GRD, which includes observations for the time period between 1997 and 2012, thus expands the observable time span by 6 years. At the same time, the two sources are slightly inconsistent in data points for the year 2004 due to a different source of data used by the two datasets. In this particular case, the inclusion of the GRD data reveals an interesting fact. While the GFS dataset only tells us that government revenues in Georgia have become more and more centralized since 2003, which may at first give the impression that this is a general long-term trend, the GRD dataset adds the information that the year 2003 was in fact a turning point in this trenduntil 2003, the country's revenues were on average becoming more decentralized.

\footnotetext{
5 The World Governance Indicators project is run by Daniel Kaufmann and Aart Kraay. The dataset as well as the methodology of its creation is available at: http://www.govindicators.org/
} 
Figure 1: Percentage of decentralized government tax revenues in Georgia over time

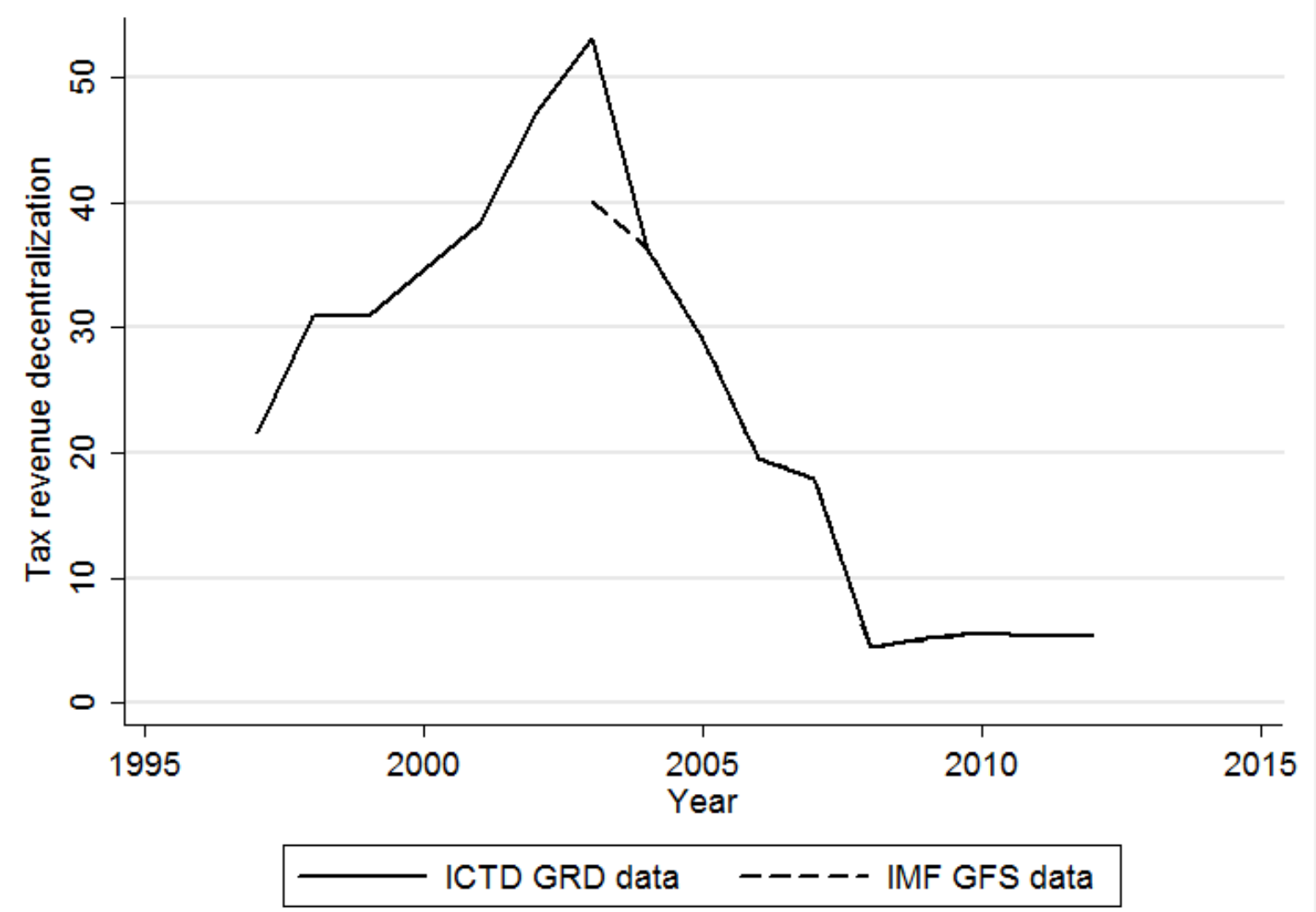

Source: GRD, GFS and authors.

In a similar fashion, we can compare the extent to which different countries collected tax revenues at the sub-national government level over time. Figure 2 presents such a comparison for selected developing countries around the world. It pinpoints the heterogeneity across countries in terms of the level of fiscal revenue decentralization, as well as the availability of data. Nevertheless, it seems that in more recent years, the distribution of revenues among different levels of government has relatively stabilized in most of these particular countries. As another example of what can be presented with the use of the GRD and GFS data, we show a simple graph in Figure A1 in the Appendix, inspired by Dziobek et al. (2011), which presents the share of the decentralized government's tax revenues on overall government tax revenues in 2011 for 62 countries. This share is lowest in small countries and in some of the most centralized countries, such as Turkey or Cyprus, and highest in some of the most decentralized countries, such as Switzerland and Canada. Romania, Uruguay, and Pakistan are among the least decentralized developing countries ${ }^{6}$. More developed countries are typically more decentralized, with only a few exceptions.

\footnotetext{
${ }^{6}$ For the classification of developing countries, we follow IMF (2015).
} 
Figure 2: Tax revenue decentralization in selected developing countries over time

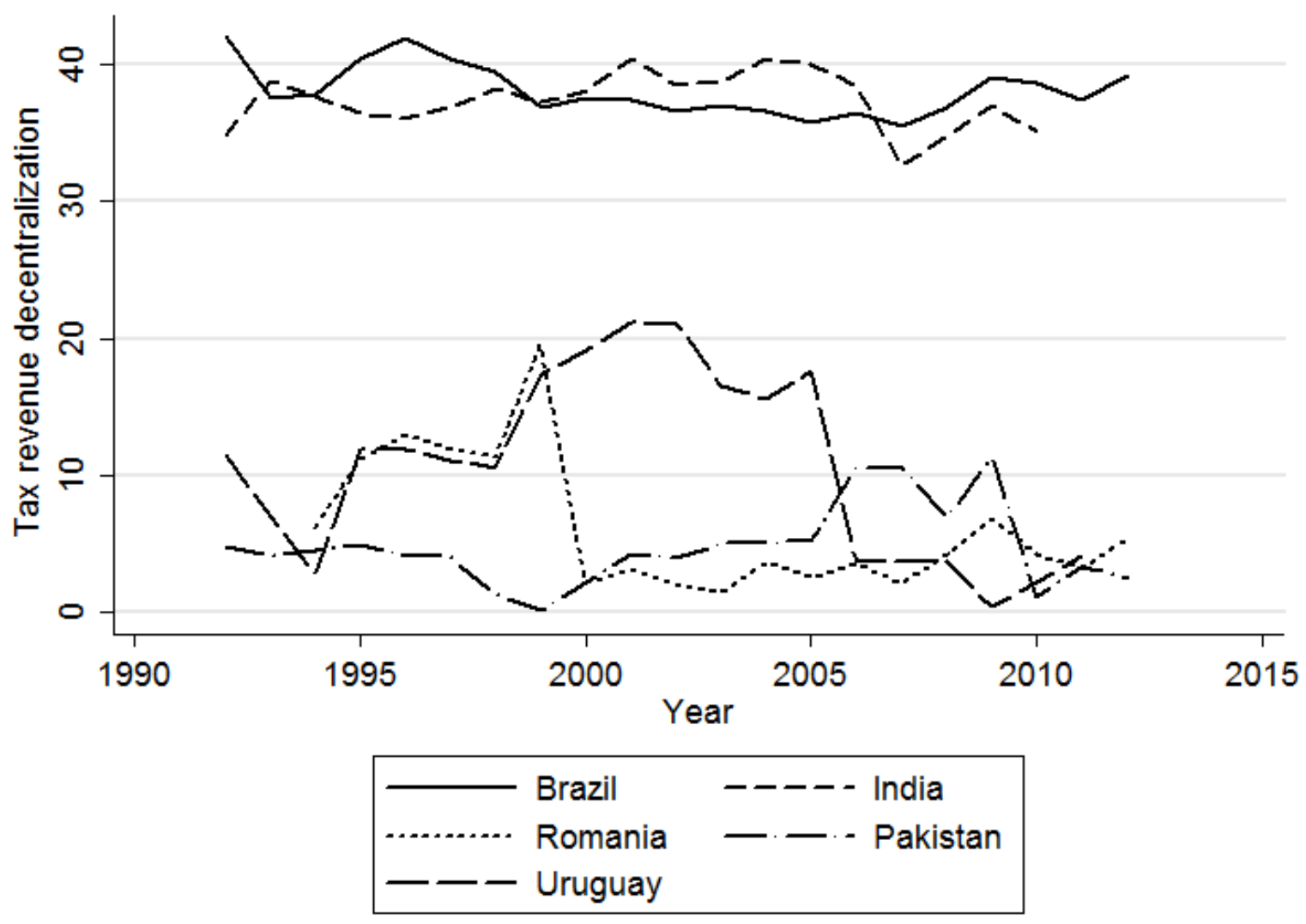

Source: GRD, GFS and authors.

To further analyse the level of decentralization in developing, low income, and transition countries as compared to other countries, we include country-specific characteristics in our merged dataset. In particular, we not only add information on whether each country is classified as a transition country (to do so, we follow IMF (2000)), but also on which income and geographic group it belongs to (for this classification, we follow the country classifications issued by the World Bank') and whether or not it is classified as a developing country (based on IMF (2015)). This enables us to construct weighted averages for the decentralization measures for each group and compare them. Furthermore, we use these variables as controls in the cross-country regressions presented in the empirical part of this paper.

As an example of the possibilities of analysing revenue decentralization over time and across groups of countries, in Figure 3 we present a graph showing weighted averages of the level of revenue fiscal decentralization for developing and developed countries over time. We observe that developing countries are, on average, more centralized than developed countries in terms of fiscal revenues. Over time, both groups seem to gradually increase their level of tax revenue decentralization.

\footnotetext{
${ }^{7}$ Available at http://data.worldbank.org/about/country-and-lending-groups
} 
Figure 3: Weighted average of the share of sub-central government tax revenues on overall government tax revenues over time in developing and developed countries

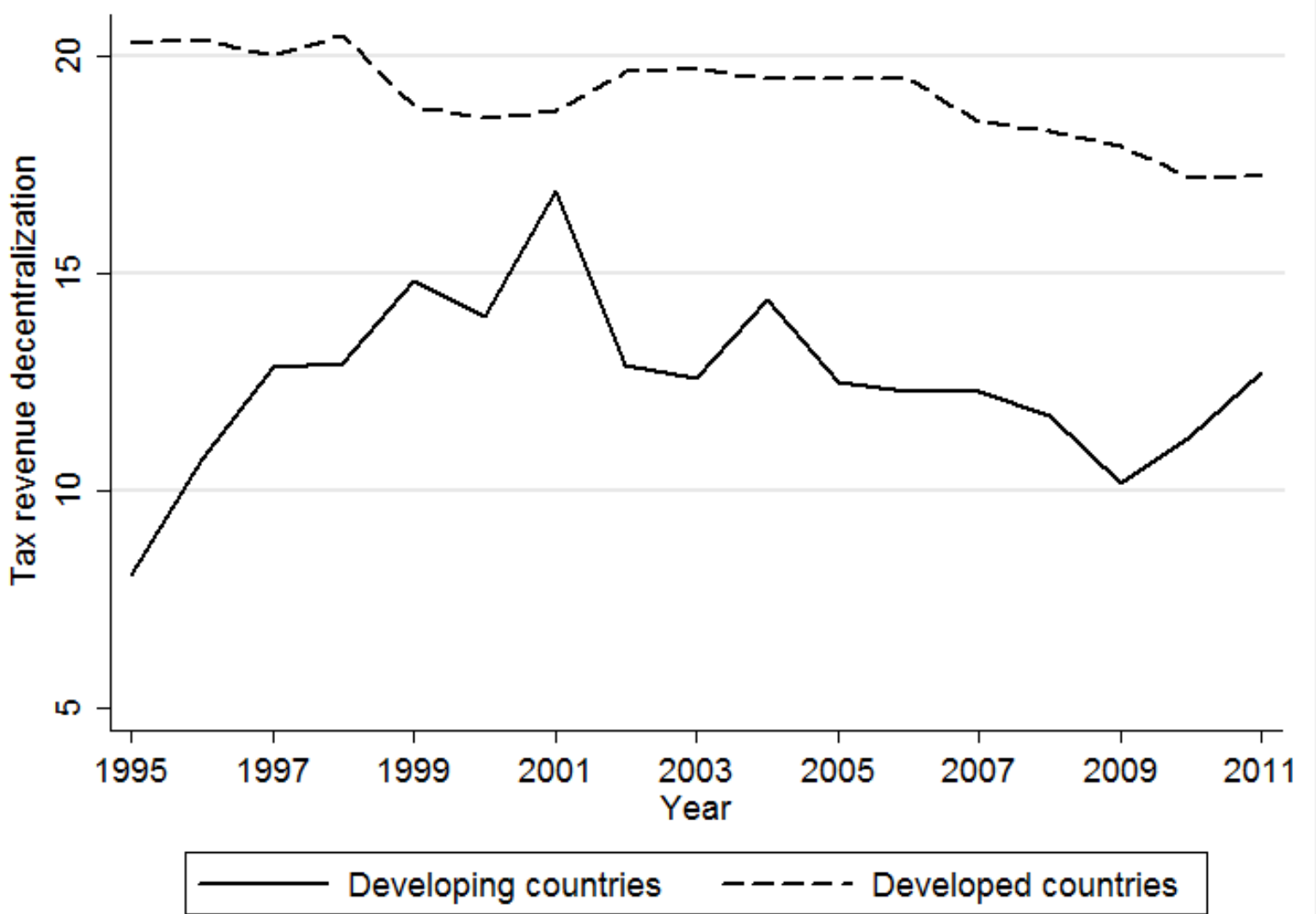

Source: GRD, GFS and authors.

\section{Econometric analysis of decentralization and the shadow economy}

Based on the literature review, we start with the assumption that fiscal decentralization can be correlated with the size of the shadow economy positively or negatively (increasing or decreasing its size) or not at all. Moreover, the relationship between decentralization and the size of the shadow economy might differ for developing and developed countries. We apply econometric methods to the best available panel data in order to examine these hypotheses empirically; however, we are not able to assess the causality of these effects, and therefore focus on observing relationships. In addition, we investigate the heterogeneity across different groups of countries to establish whether the prevailing relationship between decentralization and the size of the shadow economy is positive or negative.

We analyse the relationship between decentralization and the size of the shadow economy both by replicating previous approaches to these models and by introducing a fixed effects model that makes use of our panel dataset. We begin with basic descriptive statistics of the relationship between fiscal decentralization and the shadow economy: Figure 4 shows that the majority of countries that have high shadow economy shares (above 30 per cent) are quite centralized and are classified as developing. The most apparent exception is Russia, which has a very high share of shadow economic activity on total GDP, despite being quite decentralized in terms of government tax revenues. 
Figure 4: The relationship between decentralization measures and the size of the shadow economy; all countries with available data, classified as developing or developed according to IMF (2015); data are for the year 2011.

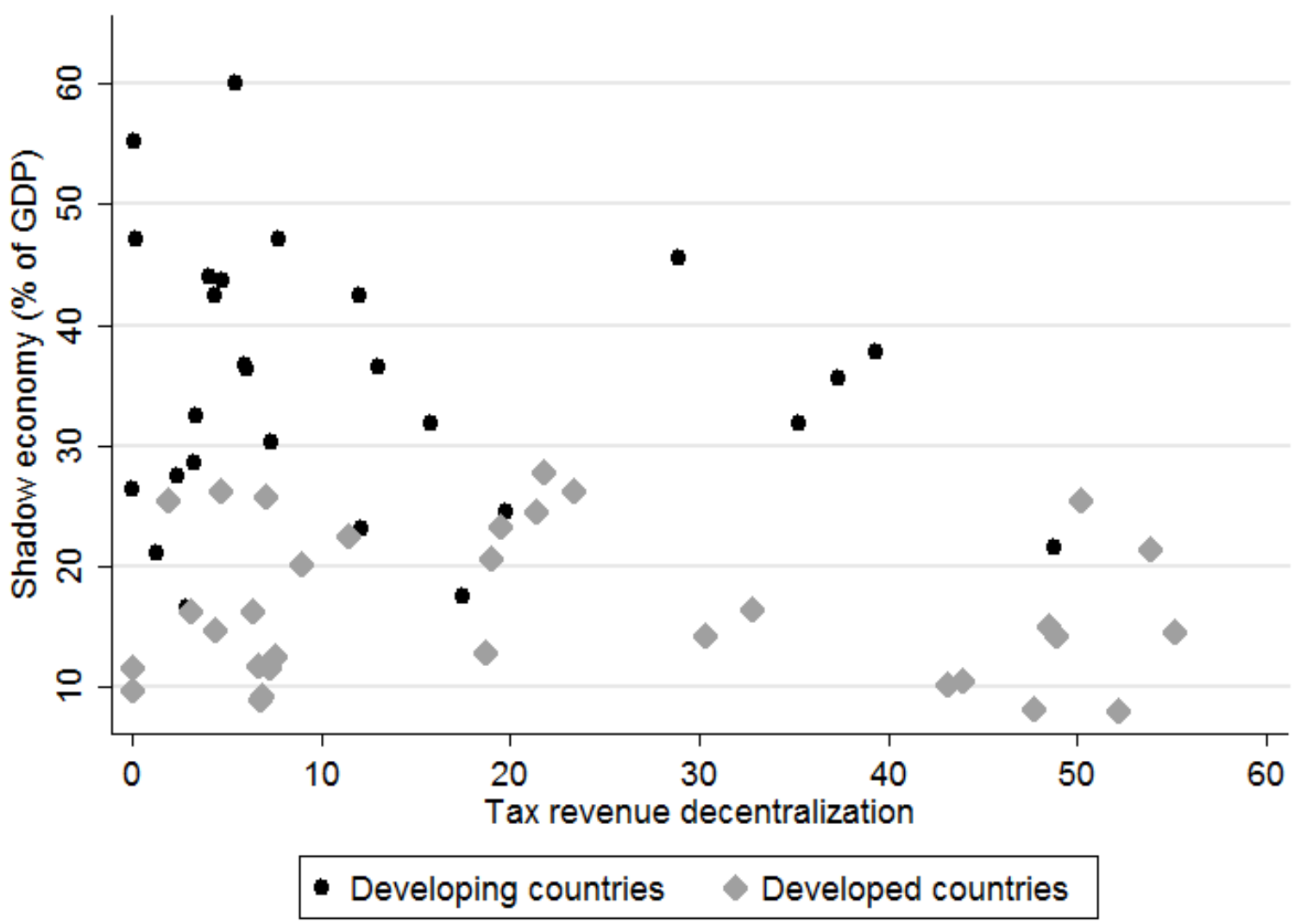

Source: GRD, IMF GFS, Elgin and Oztunali (2012), authors.

An analysis of this kind has one major drawback-the position of each dot (country) on the diagram can be explained in several different ways. The countries' heterogeneity in terms of their political systems, economic situations and institutional quality is vast. In our first model, we try to capture this heterogeneity by including a number of control variables, replicating the results reported by Buehn et al. (2013). First, we estimate a model using a dataset and other conditions as close as possible to those seen in the paper by Buehn et al. (2013). To do so, we use a subset of our dataset consisting of 73 countries and seven observations for each country for the years 19992005. In the first model, we use a cross-sectional dataset composed of observations for the year 2005. The only alteration to the data is that where observations for the year 2005 are missing, we include numbers for the closest available year, provided that this is not more than 2 years away. The model looks as follows:

$$
S E_{i}=\alpha+\sum_{j=1}^{7} \beta_{j} * X_{j, i}+\gamma * D E C_{i}+\epsilon_{i}
$$

where $S E_{i}$ represents the estimated size of the shadow economy in country $i$ as a percentage of the GDP of country $i ; \alpha$ is a fixed intercept; $X_{i}$ is a vector of seven control variables for country $i$ (GDP per capita, tax burden, unemployment rate, three regional geographical dummies and a measure of institutional quality); $D E C_{i}$ is a measure of decentralization in country $i ; \epsilon_{i}$ is the error term.

To replicate the results obtained by Buehn et al. (2013), we use the same data sources, i.e. IMF GFS for measures of decentralization and data from Schneider et al. (2010) for the estimates of 
the shadow economy. Following Buehn et al. (2013), we estimate the equation using the ordinary least squares (OLS) method and heteroskedasticity-robust standard errors. The results of the baseline regression, which do not include the decentralization measures, are displayed in column 1 of Table 1 and confirm the previous findings, suggesting that all the control variables considered in the regression are fairly suitable determinants of the size of the shadow economy. The only major difference in our results is the estimate of the effect of the Europe \& Central Asia binary variable, which is due to us likely having used a different definition of this variable compared with Buehn et al. (2013). In columns 2 and 3 of Table 1, we replicate these regressions including the fiscal decentralization measures expDec and revDec based on IMF GFS. Our results confirm the findings reported by Buehn et al. (2013) in that among the control variables used, institutional quality is the most important determinant of the size of the shadow economy across countries. However, as in Buehn et al. (2013), neither of the two coefficients for fiscal decentralization measures used in the regressions has proven statistically significant.

In columns 4 through 6, we include all available data and perform the same regressions as in columns 1 to 3 , respectively. Hereinafter we use the estimates of the size of the shadow economy calculated by Elgin and Oztunali (2012) and the revenue decentralization measure provided by the ICTD GRD, which increases our sample to 112, 59 and 62 observations for the baseline model and models including revDec and expDec, respectively. We again use the OLS method on crosssectional data with the base year 2005, complemented with observations from $+/-2$ years where data is missing for the year 2005. 
Table 1. Tax revenue decentralization and the shadow economy, year 2005 (OLS)

\begin{tabular}{|c|c|c|c|c|c|c|}
\hline & \multicolumn{3}{|c|}{$\begin{array}{l}\text { Sample restricted to that used by Buehn et al. } \\
\qquad(2013)\end{array}$} & \multicolumn{3}{|c|}{-------- Unrestricted sample ---------- } \\
\hline & (1) & (2) & (3) & (4) & (5) & (6) \\
\hline \multirow[t]{2}{*}{ GDP per capita } & $-0.223 * *$ & 0.0269 & -0.0429 & $-0.169 * * *$ & $-0.196 * *$ & -0.106 \\
\hline & $(-2.089)$ & $(0.291)$ & $(-0.487)$ & $(-2.844)$ & $(-2.318)$ & $(-1.612)$ \\
\hline \multirow[t]{2}{*}{ Tax burden } & $0.184^{*}$ & $0.167^{*}$ & $0.223^{* *}$ & $0.0969 *$ & $0.158^{* *}$ & $0.162^{* * *}$ \\
\hline & $(1.705)$ & $(1.836)$ & $(2.113)$ & $(1.932)$ & $(2.337)$ & $(2.964)$ \\
\hline \multirow[t]{2}{*}{ Unemployment } & $-0.534 * *$ & 0.176 & 0.0495 & $-0.347 * * *$ & -0.00645 & -0.137 \\
\hline & $(-2.029)$ & $(0.452)$ & $(0.153)$ & $(-2.782)$ & $(-0.0234)$ & $(-0.655)$ \\
\hline \multirow{2}{*}{$\begin{array}{l}\text { Latin America \& } \\
\text { Carribean }\end{array}$} & $10.28^{* * *}$ & $15.86^{* *}$ & $17.47 * * *$ & $5.826^{* *}$ & $10.09 * *$ & $11.05^{* *}$ \\
\hline & $(2.764)$ & $(2.105)$ & $(3.677)$ & $(2.535)$ & $(2.089)$ & $(2.119)$ \\
\hline \multirow{2}{*}{$\begin{array}{l}\text { Middle East \& North } \\
\text { Africa }\end{array}$} & -2.465 & -3.574 & -4.170 & $-6.460 * *$ & -7.142 & -5.686 \\
\hline & $(-0.753)$ & $(-0.611)$ & $(-0.772)$ & $(-2.455)$ & $(-1.408)$ & $(-1.065)$ \\
\hline \multirow[t]{2}{*}{ East and Central Asia } & $10.35^{*}$ & $12.12^{*}$ & 9.084 & $9.057 * *$ & $15.04 * * *$ & $8.325^{*}$ \\
\hline & $(1.720)$ & $(1.746)$ & $(1.503)$ & $(2.346)$ & $(2.870)$ & $(1.975)$ \\
\hline \multirow[t]{2}{*}{ Institutional quality } & $-6.065^{* * *}$ & $-8.453 * * *$ & $-9.472 * * *$ & $-7.203 * * *$ & -3.590 & $-8.180^{* * *}$ \\
\hline & $(-2.948)$ & $(-3.486)$ & $(-5.983)$ & $(-6.407)$ & $(-1.604)$ & $(-5.937)$ \\
\hline \multirow{2}{*}{$\begin{array}{l}\text { Revenue } \\
\text { decentralization }\end{array}$} & & -0.0495 & & & 0.0183 & \\
\hline & & $(-0.430)$ & & & $(0.297)$ & \\
\hline \multirow{2}{*}{$\begin{array}{l}\text { Expenditure } \\
\text { decentralization }\end{array}$} & & & 0.105 & & & 0.00891 \\
\hline & & & $(1.609)$ & & & $(0.139)$ \\
\hline \multirow[t]{2}{*}{ Constant } & $34.16^{* * *}$ & $25.35^{* * *}$ & $25.98^{* * *}$ & $34.50^{* * *}$ & $25.95^{* * *}$ & $30.54^{* * *}$ \\
\hline & $(9.963)$ & $(4.141)$ & $(5.426)$ & $(17.33)$ & $(4.981)$ & $(7.820)$ \\
\hline Observations & 67 & 46 & 44 & 112 & 59 & 62 \\
\hline R-squared & 0.705 & 0.769 & 0.842 & 0.703 & 0.729 & 0.776 \\
\hline
\end{tabular}

Notes: t-statistics based on robust standard errors are reported in parentheses, ${ }^{* *} p<0.01,{ }^{* *} p<0.05,{ }^{*} p<0.1$. While the regressions in the first three columns use estimates of the size of the shadow economy constructed by Schneider et al. (2010) as the dependent variable, in columns 4-6, we use the ones provided by Elgin and Oztunali (2012).

Source: authors' calculations.

The results of the regressions that use the unrestricted sample first confirm the findings from the baseline regression (column 4 of Table 1) in that institutional quality seems to be the most important control variable, while some other control variables lose significance. In column 5, we use the GRD data and find that the effect of tax revenue decentralization is not significant even at the 10 per cent level. As compared to a similar model that uses the restricted sample and the IMF GFS data (column 2), institutional quality and tax burden lose some of their significance, but the sign of their coefficients remains the same. In column 6 , we reach similar results with the unrestricted sample as with the restricted one.

In Table A4 in the Appendix, we provide results of regressions that include the remaining decentralization measures as explanatory variables. For employment decentralization, we use the same year as in previous regressions, i.e. 2005 , in order to make the most of the available data. 
However, for political decentralization, data are only available for the 'mid-1990s' (Fan et al. 2009). Because no data on institutional quality are available for the year 1995, we use 1996.

For employment decentralization, emplDec, we obtain similar results as for the other fiscal decentralization measures (see Table 1) - the estimate of the decentralization coefficient is not statistically significant. The same generally applies to the political decentralization measures, where we do not detect that decentralization is statistically significantly associated with fluctuations in the size of the shadow economy using cross-sectional analysis and the OLS estimation. The only statistically significant coefficient obtained is for lowUnitElDec, and as expected, this estimate is negative.

There are at least four possible interpretations of the results of the replications of previous approaches. First, fiscal decentralization does not influence the size of the shadow economy enough to prove statistically significant in the cross-sectional model. Second, some other variables correlated with the measures of fiscal decentralization influence the size of the shadow economy and these make our estimates of the ceteris paribus effect of fiscal decentralization on the size of the shadow economy insignificant. Third, there is a relationship between the size of the shadow economy and decentralization, but the relatively poor quality and availability of data makes it impossible to detect the details of this relationship. Fourth, there exists a causal relationship between decentralization and the size of the shadow economy, which makes our estimates biased. We therefore develop a fixed effects model and run a series of test to determine whether one of these possible explanations is plausible.

Estimates obtained using panel data techniques have numerous advantages over the simple pooled OLS estimation procedures (Baltagi 2008). Specifically, the OLS method cannot adjust for country-specific and time-specific effects. We employ similar data as in our previous models, which follow Buehn et al. (2013), but use panel data with a varying intercept for each country, which allows us to mitigate the risk of omitted variable bias. Using statistical tests, we determine that country-specific characteristics are not randomly generated from a normal distribution and are correlated with other explanatory variables in the model. Specifically, we employ the Hausman specification test (Hausman 1978) which rejects at the 1 per cent level of significance the null hypothesis of no systematic differences between the coefficients obtained through random effects and fixed effects estimation. Therefore, we use the fixed effects estimation. The model can be described in the following way:

$$
S E_{i}=\alpha+\sum_{j=1}^{n} \beta_{j} * X_{j, i}+\gamma * D E C_{i}+\delta * D E C_{i} * d e v_{i}+\epsilon_{i}
$$

where $S E_{i}$ is the estimated size of the shadow economy in country $i ; X_{j, i}$ is a set of four control variables generally proven to have an effect on the size of the shadow economy in some settings (GDP per capita, tax burden, unemployment and institutional quality); $D E C_{i}$ is a measure of decentralization; $d e v_{i}$ is a binary variable indicating whether or not country $i$ is classified as a developing country according to (IMF 2015); and $\epsilon_{i}$ is the error term.

The fundamental advantage of estimating the model using a panel data framework is that countryspecific variables that are difficult to observe are accounted for by allowing the intercept to vary across countries. Table 2 presents the results of estimating the model using the fixed effects 
regression. ${ }^{8}$ The results of the complete model, presented in column 4 , suggest that in the developed countries, an increase in tax revenue decentralization is associated with a small and significant decrease in the size of the shadow economy, while for developing countries, the effect becomes positive, meaning that more decentralized tax revenues are associated with a higher share of the shadow economic activities. We find that as expected, institutional quality and GDP per capita all have a small decreasing effect on the size of the shadow economy.

Table 2. Tax revenue decentralization and the shadow economy (panel data fixed effects, all countries)

(1)

GDP per capita

Tax burden

Unemployment rate

Institutional quality

Revenue decentralization

Revenue decentralization

* Developing (binary)

Constant

\section{$-0.0898^{* * *}$

(2)

$$
\begin{gathered}
-0.0878^{* * *} \\
(-10.77)
\end{gathered}
$$$$
-0.113^{* * *}
$$$$
(-4.087)
$$

$$
\begin{gathered}
\\
\\
-0.0312 \\
(-1.447) \\
0.128^{* * *} \\
(4.547) \\
29.05^{* * *}
\end{gathered}
$$

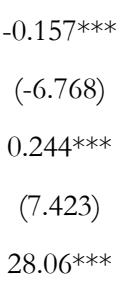

(72.68)

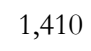

0.148

54
(3)

$-0.0855^{* * *}$
$(-10.55)$

$-0.107 * * *$

(-3.894)

0.0209

(0.770)

(4)

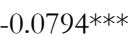

(-9.482)

$-0.0622^{* *}$

$(-2.238)$

0.0178

(0.661)

$-3.318^{* * *}$

(-6.528)

$-0.0737 * * *$

$(-3.060)$

$0.154 * * *$

30.86***

(37.33)

763

612

0.217

0.278

0.214

54

54

Notes: t-statistics based on robust standard errors are reported in parentheses, ${ }^{* * *} p<0.01,{ }^{* *} p<0.05,{ }^{*} p<0.1$. In all regressions, we use the estimates of the size of the shadow economy provided by Elgin and Oztunali (2012) as dependent variables.

Source: authors.

Overall, the regression results in Table 2 provide evidence of a small but relatively robust and statistically significant relationship between fiscal revenue decentralization and the size of the shadow economy in the developing countries: the higher the level of decentralization, the greater the size of the shadow economy. As expected, the estimates of the effect of GDP per capita and institutional quality have a negative sign and are statistically significant. Institutional quality and tax burden also have a strong explanatory power, with the effect of tax burden being unexpectedly slightly negative.

Overall, we find evidence of a relatively robust and statistically significant relationship between fiscal revenue decentralization and the size of the shadow economy. In developing countries, our

\footnotetext{
8 The complete list of countries examined in this section is given in Table A5 in the Appendix.
} 
estimates suggest that the more decentralized the country is in terms of fiscal revenues, the larger its shadow economy is. Weaker control over local officials (and their resulting lower accountability), lower public spending, and administration effectiveness due to a lack of expertise and human resources, or greater heterogeneity across regions in terms of administrative requirements for businesses, are all examples of channels through which this effect may be pronounced, especially in developing countries.

In developed countries, we find evidence of the opposite effect: higher levels of decentralization are associated with smaller sizes of shadow economies. This result is also in line with our theoretical discussion above. If we assume that the general public is able to and willing to control the actions of local public officers and hold them adequately accountable, and that these local public officers are capable of effective governance, higher levels of decentralization may provide citizens with greater motivation to keep their activities in the formal sector. This is more likely to be the case in relatively more developed countries.

Using other estimates of the size of the shadow economy in models that employ panel data is difficult, since the time period covered by the other estimates is not sufficient to estimate a fixed effects model. We do, however, perform checks of robustness to the use of these other sources for the cross-sectional models, as described above.

\section{Conclusion}

In this paper we use the new GRD complemented by the IMF GFS to analyse fiscal decentralization in both developing and developed countries. We have reviewed both early and recent literature on decentralization and shadow economies and hypothesized that decentralization may affect the shadow economy either negatively or positively, increasing or decreasing its size. In our empirical analysis, we have studied this relationship using descriptive statistics and replicated the results obtained in the recent literature on this topic. We have then used our novel merged dataset to estimate a fixed effects model and to provide evidence supporting our theoretical considerations.

Our results suggest that in developing countries the fiscal decentralization has a positive effect on the size of the shadow economy, i.e. a higher level of decentralization is associated with a larger shadow economy, while in developed countries the opposite effect prevails. This effect can be explained by the differing characteristics of local government units between developing and developed countries, which means that the effect of decentralization is likely to be different in developing and developed countries.

The paper makes two key contributions to the field. First, we are the first to use the GRD dataset to study fiscal decentralization, in terms of both tax revenues and expenditures. By combining the GRD data with the IMF GFS data, we make use of the best available data to analyse fiscal decentralization in both developing and developed countries. Second, we are the first to empirically examine the relationship of fiscal decentralization and the size of the shadow economy using panel data and the fixed effects framework.

At least three areas are still in need of further research. The first concerns the measurement of fiscal decentralization. The GRD only includes information on revenues, including taxes, and not on expenditures. Ideally, further development of the GRD might lead to the inclusion of expenditures in a similar way to revenues, which would provide researchers with high-quality data for measuring expenditure-based fiscal decentralization. The second concerns the relationship 
between fiscal decentralization and the shadow economy. The empirical analysis in this area is weakened by the relatively low quality of shadow economy estimates. More elaborate ways of testing shadow economies, possibly using some suitable microeconomic data, would be bound to produce more definitive conclusions on the relationships we have investigated. The third area for further research would address questions that have not yet been properly addressed in this paper or the previous literature, for various reasons. For example, when tax revenue is increasing and economic growth is stagnating, does the size of the shadow economy increase because people feel the squeeze from both the public and private sectors? The answers to this and other similar questions would lend important insights relevant to the relationship between decentralization and shadow economies.

\section{References}

Alm, J., and A. Embaye (2013). 'Using dynamic panel methods to estimate shadow economies around the world, 1984-2006'. Public Finance Review, 41(5): 510-543.

Baltagi, B. (2008). 'Econometric analysis of panel data'. Hoboken, New Jersey, USA: John Wiley $\&$ Sons.

Bird, R.M., R.D. Ebel, C.I. Wallich, and W. Oates (1998). 'Fiscal decentralization: from command to market'. Romania, 35(21.7): 3-7.

Bittencourt, M., R. Gupta, and L. Stander (2014). 'Tax evasion, financial development and inflation: Theory and empirical evidence'. Journal of Banking \& Finance 41: 194-208.

Breton, A. (1998). 'Competitive governments: An economic theory of politics and public finance'. Cambridge, UK: Cambridge University Press.

Buehn, A., C. Lessmann, and G Markwardt (2013). 'Decentralization and the shadow economy: Oates meets Allingham-Sandmo’. Applied Economics, 45(18): 2567-2578.

Dabla-Norris, E. (2006). 'The challenge of fiscal decentralisation in transition countries'. Comparative Economic Studies, 48(1): 100-131.

Dell'Anno, R. (2007). 'The shadow economy in Portugal: an analysis with the MIMIC approach'. Journal of Applied Economics, 10(2): 253.

Dell'Anno, R., and O.H. Solomon (2008). 'Shadow economy and unemployment rate in USA: is there a structural relationship? An empirical analysis'. Applied Economics, 40(19): 2537-2555.

Donahue, J.D. (1997). 'Disunited states'. New York, USA: BasicBooks.

Dreher, A. and F. Schneider (2010). 'Corruption and the shadow economy: an empirical analysis'. Public Choice, 144(1-2): 215-238.

Dziobek, C., C.A. Gutierrez Mangas, and P. Kufa (2011). 'Measuring Fiscal DecentralizationExploring the IMF's Databases'. Washington DC, USA: IMF Working Papers, 1-30.

Elgin, C. and O. Oztunali (2012). Shadow Economies around the World: Model Based Estimates. Bogazici University Department of Economics Working Papers, 5: 1-48.

Fan, C.S., C. Lin and D. Treisman (2009). 'Political decentralization and corruption: Evidence from around the world'. Journal of Public Economics, 93(1): 14-34.

Feld, L.P. and F. Schneider (2010). 'Survey on the shadow economy and undeclared earnings in OECD countries'. German Economic Review, 11(2): 109-149.

Goel, R.K. and J.W. (2014). 'Global corruption and the shadow economy: spatial aspects'. Public Choice, 161(1-2): 119-139. 
Hausman, J.A. (1978). 'Specification tests in econometrics'. Econometrica: Journal of the Econometric Society, 1251-1271.

IMF, (2015). World Economic Outlook: Uneven Growth-Short- and Long-Term Factor. Washington DC, USA: International Monetary Fund.

IMF, (2000). An IMF perspective on Progress and Prospects. IMF Report

Inman, R.P. (2003). 'Transfers and bailouts: Enforcing local fiscal discipline with lessons from US federalism'. Fiscal decentralization and the challenge of hard budget constraints, 35: 59.

Johnson, S., D. Kaufmann, and P. Zoido-Lobaton (1998a). 'Regulatory discretion and the unofficial economy'. American Economic Review, 88(2): 387-392.

Johnson, S., D. Kaufmann, and P. Zoido-Lobaton (1998b). 'Corruption, public finances and the unofficial economy'. Washington DC, USA: World Bank.

McCullough, J., T. Spofford, E. Savov, and S. Ivanov (2000). 'Bulgaria: Comprehensive municipal finance and fiscal reform proposal'. Sofia, Bulgaria: USAID (US Agency for International Development), The Urban Institute.

Musgrave, R.A. (1956). 'A multiple theory of budget determination'. FinanaArchiv/Public Finance Analysis, (H3), 333-343.

Oates, W.E. (1999). 'An essay on fiscal federalism'. Journal of Economic Literature, 37(3): 1120-1149.

Pappa, E., R. Sajedi, and E. Vella (2015). 'Fiscal consolidation with tax evasion and corruption'. Journal of International Economics, 96: S56-S75.

Prichard, W., A. Cobham, and A. Goodall (2014). 'The ICTD Government Revenue Dataset'. (ICTD Working Papers 19). Brighton, UK: International Center for Tax and Development.

Prud'Homme, R. (1995). 'The dangers of decentralization'. The World Bank Research Observer, 10(2): 201-220.

Putnam, R.D., R. Leonardi, and R.Y. Nanetti (1994). 'Making democracy work: Civic traditions in modern Italy'. Princeton, New Jersey, USA: Princeton University Press.

Rodríguez-Pose, A. and R. Ezcurra (2011). 'Is fiscal decentralization harmful for economic growth? Evidence from the OECD countries'. Journal of Economic Geography, 11(4): 619-643.

Rodríguez-Pose, A., and N. Gill (2005). 'On the "economic dividend" of devolution'. Regional Studies, 39(4): 405-420.

Samuelson, P.A. (1954). 'The pure theory of public expenditure'. The Review of Economics and Statistics, 387-389.

Schneider, F., A. Buehn, and C.E. Montenegro (2010). 'Shadow Economies all over the World: New Estimates for 162 Countries from 1999 to 2007'. Washington DC, USA: World Bank.

Seiferling, M.M. (2013). 'Recent Improvements to the Government Finance Statistics Yearbook database in response to analytical needs'. Washington DC, USA: International Monetary Fund.

Storper, M. (2005). 'Society, community, and economic development'. Studies in Comparative International Development, 39(4): 30-57.

Tafenau, E., H. Herwartz, and F. Schneider (2010). 'Regional estimates of the shadow economy in Europe'. International Economic Journal, 24(4): 629-636.

Teobaldelli, D. (2011). 'Federalism and the shadow economy'. Public Choice, 146(3-4): 269-289.

Tiebout, C.M. (1956). 'A Pure Theory of Local Expenditures'. Journal of Political Economy, 64(5): 416-424. 
Torgler, B., F. Schneider, and C.A. Schaltegger (2010). 'Local autonomy, tax morale, and the shadow economy'. Public Choice, 144(1-2): 293-321.

Wetzel, D. And A. Papp (2003). 'Strengthening Hard Budget Constraints in Hungary'. In J.A.Roden, G.S.Eskeland and J.Litvack (eds.), Fiscal Decentralization and the Challenge of Hard Budget Constraints. Cambridge, Massachusetts, USA: The MIT Press. 


\section{Appendix}

Table A1: Definitions and sources of used variables

\begin{tabular}{|c|c|}
\hline Variable & Definition \\
\hline GDPpc & Gross domestic product divided by midyear population (current US\$ thousands). \\
\hline Unemployment & $\begin{array}{l}\text { The share of the labour force that is without work but available for and seeking } \\
\text { employment (per cent of total labour force). }\end{array}$ \\
\hline Tax burden & $\begin{array}{l}\text { Total tax revenue at the general level of government, including social contributions } \\
\text { (percent of GDP). }\end{array}$ \\
\hline IQ & $\begin{array}{l}\text { Institutional quality, measured as the mean of three WGIs-government effectiveness, } \\
\text { rule of law, control of corruption. }\end{array}$ \\
\hline revDec & $\begin{array}{l}\text { Fiscal revenue decentralization measured as the share of taxes collected at the sub- } \\
\text { national government level on total general government tax revenues. }\end{array}$ \\
\hline expDec & $\begin{array}{l}\text { Fiscal expenditure decentralization measured as the share of expenditures at the sub- } \\
\text { national government level on total general government expenditures. }\end{array}$ \\
\hline emplDec & $\begin{array}{l}\text { Fiscal employment decentralization measured as the share of employee compensation at } \\
\text { the sub-national level on total general government employee compensation. }\end{array}$ \\
\hline tiersDec & The number of levels at which there exists a state executive body. \\
\hline bottomUnitSizeDec & $\begin{array}{l}\text { The average number of people living within the jurisdiction of each lowest government } \\
\text { unit, calculated as the number of lowest-tier government units divided by total } \\
\text { population. Population data are from the World Bank. }\end{array}$ \\
\hline lowUnitElDec & $\begin{array}{l}\text { The sum of the variables } B T E \text { and } S L T E \text { from Fan et al. (2009). Each of these take the } \\
\text { value one if the public officers at the lowest and second-lowest government level, } \\
\text { respectively, are elected directly or chosen through a directly elected local assembly, and } \\
\text { zero if these officers are appointed by higher level officers. }\end{array}$ \\
\hline
\end{tabular}

World Bank

World

Governance

Indicators

GRD

\section{IMF GFS}

\section{IMF GFS}

Fan et al. (2009)

Fan et al. (2009),

World Bank

Fan et al. (2009)

\section{Source: authors' construction.}


Table A2: Summary statistics of used variables

\begin{tabular}{|c|c|c|c|c|c|c|}
\hline Variable & Definition & Obs & Mean & Std. Dev. & Min & $\operatorname{Max}$ \\
\hline SE_elgin & $\begin{array}{c}\text { Size of the shadow } \\
\text { economy based on } \\
\text { (Elgin and } \\
\text { Oztunali, 2012) }\end{array}$ & 2929 & 29.631 & 16.149 & 7.965 & 112.919 \\
\hline SE_alm & $\begin{array}{c}\text { Size of the shadow } \\
\text { economy based on } \\
\text { (Alm and Embaye, } \\
\text { 2013) }\end{array}$ & 950 & 25.269 & 10.283 & 10.4 & 68.2 \\
\hline SE_schneider & $\begin{array}{c}\text { Size of the shadow } \\
\text { economy based on } \\
\text { (Schneider et al., } \\
\text { 2010) }\end{array}$ & 501 & 26.227 & 12.712 & 8.1 & 68.3 \\
\hline GDPpc & GDP per capita & 2474 & 11.204 & 14.957 & 0.0701 & 113.727 \\
\hline Tax burden & Total tax revenue & 1686 & 22.906 & 7.616 & 5.399 & 48.431 \\
\hline Unemployment & $\begin{array}{l}\text { Unemployment } \\
\text { rate }\end{array}$ & 1275 & 8.976 & 5.807 & 0.7 & 37.3 \\
\hline IQ & $\begin{array}{l}\text { Institutional quality, } \\
\text { based on WGI }\end{array}$ & 827 & 0.687 & 0.959 & -1.207 & 2.297 \\
\hline revDec & $\begin{array}{c}\text { Revenue } \\
\text { decentralization }\end{array}$ & 1440 & 22.104 & & 0 & 80.286 \\
\hline expDec & $\begin{array}{c}\text { Expenditure } \\
\text { decentralization }\end{array}$ & 808 & 18.712 & 13.503 & 0.725 & 67.952 \\
\hline emplDec & $\begin{array}{c}\text { Employment } \\
\text { decentralization } \\
\text { Number of }\end{array}$ & 823 & 45.273 & 26.118 & 0 & 89.31 \\
\hline tiersDec & $\begin{array}{l}\text { government levels } \\
\text { with a state } \\
\text { executive body }\end{array}$ & 72 & 3.625 & 0.735 & 2 & 5 \\
\hline bottomUnitSizeDec & $\begin{array}{l}\text { Number of lowest- } \\
\text { tier government } \\
\text { units divided by } \\
\text { total population }\end{array}$ & 70 & 15513.08 & 29359.72 & 918.413 & 169726.7 \\
\hline lowUnitEIDec & $\begin{array}{l}\text { Measure of directly } \\
\text { elected public } \\
\text { officials at the } \\
\text { lowest-tier } \\
\text { government level }\end{array}$ & 56 & 1.464 & 0.617 & 0 & 2 \\
\hline
\end{tabular}


Table A3: Size of the shadow economy and fiscal decentralization measures, 2005

\begin{tabular}{|c|c|c|c|c|c|c|}
\hline Country & SE_elgin & SE_alm & SE_schneider & revDec & expDec & emplDec \\
\hline Argentina & 23.4 & 29.9 & 24.7 & 43.9 & & \\
\hline Armenia & 45.6 & 37.1 & 42.7 & 7.6 & 1.2 & 10.4 \\
\hline Australia & 13.9 & 15.1 & 13.7 & 17.8 & 25.9 & 72.3 \\
\hline Austria & 9.5 & 13.9 & 9.8 & 9.6 & 20.3 & 45.8 \\
\hline Belarus & 46.4 & 39.5 & 45.2 & 8.6 & 30.9 & 62.6 \\
\hline Belgium & 21.6 & & 21.8 & 17.9 & 15.0 & 76.0 \\
\hline Brazil & 36.7 & 33.0 & 38.4 & 35.7 & & \\
\hline Bulgaria & 33.8 & 35.8 & 34.1 & 7.2 & 5.3 & 39.8 \\
\hline Canada & 15.7 & 12.2 & 15.5 & 52.4 & 53.3 & 82.2 \\
\hline Chile & 19.1 & 26.2 & 18.9 & 15.3 & 8.9 & 26.8 \\
\hline China & 12.6 & 23.2 & 12.5 & 44.2 & & \\
\hline Colombia & 34.5 & 42.2 & 36.1 & & & \\
\hline Costa Rica & 46.0 & 29.0 & 25.6 & 3.4 & 2.9 & 3.9 \\
\hline Croatia & 31.4 & 29.5 & 31.3 & 11.7 & 9.6 & 8.9 \\
\hline Cyprus & 26.8 & 29.1 & 27.7 & 1.6 & & 5.1 \\
\hline Czech Republic & 17.3 & 23.8 & 17.8 & 2.8 & 15.0 & 23.8 \\
\hline Denmark & 17.3 & 17.2 & 17.6 & 34.4 & 38.5 & 73.7 \\
\hline El Salvador & 43.5 & 31.3 & 44.5 & & 3.6 & 6.5 \\
\hline Estonia & 31.1 & 28.5 & 30.5 & 19.3 & 16.3 & 41.5 \\
\hline Finland & 17.3 & & 17.4 & 28.7 & 27.7 & 73.0 \\
\hline France & 14.9 & 18.9 & 14.8 & 38.1 & 13.9 & 23.3 \\
\hline Georgia & 65.6 & & 65.1 & 29.0 & 23.7 & 38.7 \\
\hline Germany & 15.3 & 12.9 & 16.0 & 49.4 & 33.4 & 78.5 \\
\hline Greece & 27.0 & 18.5 & 26.9 & 3.3 & 2.3 & 9.1 \\
\hline Hungary & 24.1 & 29.8 & 24.0 & 20.9 & 13.2 & 51.6 \\
\hline Iceland & 15.8 & 16.2 & 15.1 & 25.0 & 27.2 & 37.4 \\
\hline India & 22.0 & 22.3 & 21.7 & 40.0 & 35.5 & 74.8 \\
\hline Iran & 17.5 & 24.3 & 18.1 & 15.9 & 4.6 & 3.3 \\
\hline Ireland & 15.9 & & 15.6 & 2.9 & 7.8 & 16.4 \\
\hline Israel & 20.8 & & 21.8 & & 6.8 & 15.1 \\
\hline Italy & 27.1 & 22.4 & 27.1 & 24.4 & 19.0 & 41.8 \\
\hline Japan & 10.4 & 17.6 & 10.7 & 40.0 & 66.1 & 80.2 \\
\hline Latvia & 28.8 & 25.4 & 28.4 & 52.5 & 17.7 & 46.9 \\
\hline Luxembourg & 9.6 & 15.5 & 9.7 & 6.4 & 6.8 & 23.5 \\
\hline Macedonia & 34.9 & & 36.9 & & & \\
\hline Moldova & 45.8 & 35.8 & 43.4 & 17.9 & 16.0 & 48.3 \\
\hline Netherlands & 13.1 & 14.6 & 13.2 & 6.9 & 11.9 & 65.6 \\
\hline New Zealand & 12.3 & 17.5 & 12.1 & 5.3 & 8.7 & 7.8 \\
\hline Pakistan & 34.1 & 28.3 & 34.9 & 5.3 & & \\
\hline Paraguay & 36.8 & 39.6 & 38.2 & 5.1 & 5.0 & 8.4 \\
\hline Poland & 26.7 & 26.4 & 26.9 & 20.6 & 14.6 & 56.4 \\
\hline Portugal & 23.3 & 18.6 & 23.3 & 13.9 & 9.1 & 13.8 \\
\hline Romania & 30.6 & & 31.7 & 2.6 & 21.3 & 38.0 \\
\hline Slovak Republic & 17.1 & 25.5 & 17.6 & 5.3 & 11.3 & 41.0 \\
\hline
\end{tabular}




\begin{tabular}{lcccccc} 
Slovenia & 25.4 & 29.3 & 25.8 & 13.5 & 8.8 & 34.4 \\
South Africa & 25.8 & 44.1 & 26.5 & & 16.9 & 64.4 \\
South Korea & 26.3 & 17.0 & 26.3 & 22.0 & & \\
Spain & 22.7 & 16.0 & 22.4 & 46.6 & 33.8 & 77.0 \\
Sweden & 18.1 & 14.0 & 18.6 & 44.4 & 34.9 & 76.7 \\
Switzerland & 8.1 & 12.7 & 8.5 & 53.4 & 48.4 & 88.5 \\
Thailand & 49.0 & 36.1 & 49.0 & 8.3 & 5.8 & 13.4 \\
Turkey & 30.8 & 35.8 & 30.0 & 2.0 & & \\
Ukraine & 47.6 & 37.2 & 47.8 & 23.1 & 14.1 & 53.3 \\
United Kingdom & 12.4 & 16.9 & 12.4 & 6.5 & 8.5 & 46.1 \\
United States & 8.6 & 13.1 & 8.5 & 45.4 & 39.7 & 71.9 \\
Uruguay & 46.4 & 37.2 & 49.2 & 17.6 & & \\
\hline
\end{tabular}

Source: Elgin and Oztunali (2012), Alm and Embaye (2013), Schneider et al. (2010), GRD, IMF GFS, authors. 
Table A4. Employment decentralization, political decentralization and the shadow economy (OLS)

\begin{tabular}{|c|c|c|c|c|}
\hline & $(1)$ & $(2)$ & (3) & (4) \\
\hline \multirow[t]{2}{*}{ GDP per capita } & $-0.187^{* *}$ & 0.101 & -0.276 & 0.111 \\
\hline & $(-2.658)$ & $(0.369)$ & $(-0.998)$ & $(0.327)$ \\
\hline \multirow[t]{2}{*}{ Tax burden } & 0.232 & -0.137 & -0.0842 & 0.0403 \\
\hline & $(1.618)$ & $(-0.481)$ & $(-0.234)$ & $(0.116)$ \\
\hline \multirow[t]{2}{*}{ Unemployment rate } & -0.216 & 0.0194 & -0.167 & -0.116 \\
\hline & $(-1.033)$ & $(0.0514)$ & $(-0.437)$ & $(-0.318)$ \\
\hline \multirow[t]{2}{*}{ Latin America \& Carribean } & $9.762^{\star *}$ & & 7.419 & 4.585 \\
\hline & $(2.096)$ & & $(1.211)$ & $(0.810)$ \\
\hline \multirow[t]{2}{*}{ Middle East \& North Africa } & -8.692 & & & \\
\hline & $(-1.342)$ & & & \\
\hline \multirow[t]{2}{*}{ Europe \& Central Asia } & $7.947^{*}$ & & 6.257 & \\
\hline & $(1.749)$ & & $(1.250)$ & \\
\hline \multirow[t]{2}{*}{ Institutional quality } & $-7.994^{\star * *}$ & $-7.190^{* *}$ & $-6.051^{*}$ & $-8.959^{* *}$ \\
\hline & $(-5.126)$ & $(-2.074)$ & $(-1.983)$ & $(-2.634)$ \\
\hline \multirow[t]{2}{*}{ Employment decentralization } & 0.0132 & & & \\
\hline & $(0.436)$ & & & \\
\hline \multirow{2}{*}{$\begin{array}{l}\text { Employment decentralization } \\
\text { * Developing (binary) }\end{array}$} & -0.0127 & & & \\
\hline & $(-0.212)$ & & & \\
\hline \multirow[t]{2}{*}{ tiersDec } & & -2.630 & & \\
\hline & & $(-1.127)$ & & \\
\hline \multirow{2}{*}{$\begin{array}{l}\text { tiersDec } \\
\text { * Developing (binary) }\end{array}$} & & $3.177^{\star * *}$ & & \\
\hline & & $(2.765)$ & & \\
\hline \multirow[t]{2}{*}{ bottomUnitSizeDec } & & & $-7.63 e-05$ & \\
\hline & & & $(-0.671)$ & \\
\hline \multirow{2}{*}{$\begin{array}{l}\text { bottomUnitSizeDec } \\
\text { * Developing (binary) }\end{array}$} & & & $6.57 e-05$ & \\
\hline & & & $(0.577)$ & \\
\hline \multirow[t]{2}{*}{ lowUnitEIDec } & & & & $-8.563^{*}$ \\
\hline & & & & $(-1.957)$ \\
\hline \multirow{2}{*}{$\begin{array}{l}\text { lowUnitEIDec } \\
\text { * Developing (binary) }\end{array}$} & & & & 2.536 \\
\hline & & & & $(0.870)$ \\
\hline \multirow[t]{2}{*}{ Constant } & $30.43^{* * *}$ & $39.35^{\star \star \star}$ & $38.20^{\star \star \star}$ & $43.59 * * *$ \\
\hline & $(8.221)$ & $(3.427)$ & $(4.699)$ & $(4.115)$ \\
\hline Observations & 62 & 52 & 50 & 40 \\
\hline R-squared & 0.773 & 0.509 & 0.510 & 0.591 \\
\hline
\end{tabular}

Notes: t-statistics based on robust standard errors are reported in parentheses, ${ }^{* * *} p<0.01,{ }^{* *} p<0.05,{ }^{*} p<0.1$. In all regressions, we use the estimates of the size of the shadow economy provided by Elgin and Oztunali (2012) as dependent variables.

Source: authors.

Table A5. List of countries used in the analysis

Argentina, Armenia, Australia, Austria, Belarus, Belgium, Brazil, Bulgaria, Canada, Chile, China, Colombia, Costa Rica, Croatia, Cyprus, Czech Republic, Denmark, El Salvador, Estonia, Finland, France, Georgia,

Germany, Greece, Hungary, Iceland, India, Iran, Ireland, Israel, Italy, Japan, Latvia, Luxembourg, Macedonia, Moldova, Netherlands, New Zealand, Pakistan, Paraguay, Poland, Portugal, Romania, Slovak Republic, Slovenia, South Africa, South Korea, Spain, Sweden, Switzerland, Thailand, Turkey, Ukraine, United Kingdom, United States, Uruguay

Source: authors. 
Figure A1: Share of government tax revenues at the sub-central level on overall government tax revenues in 2011. Developing countries are highlighted in grey

\section{Tax revenue decentralization}

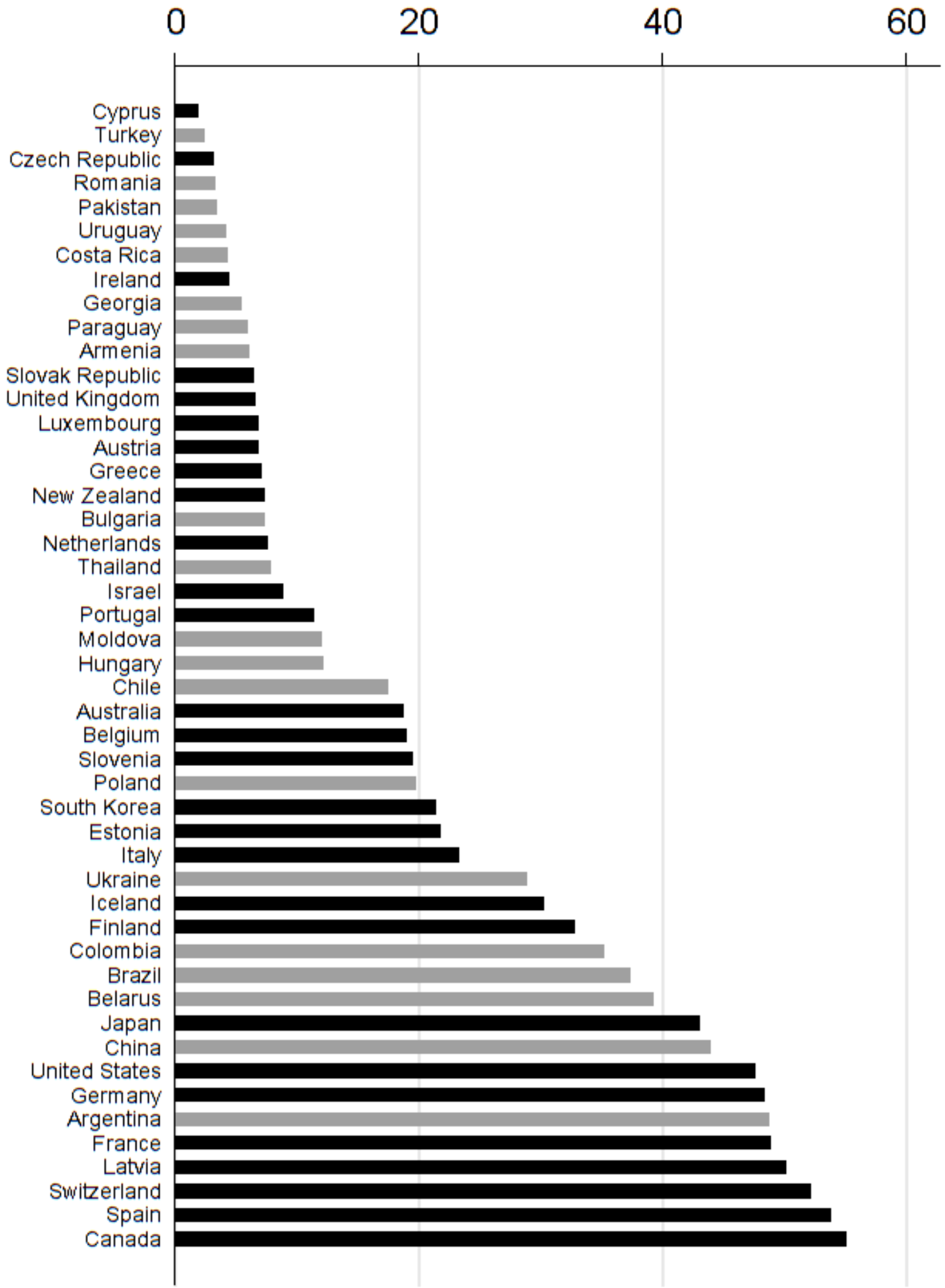

Source: GRD, GFS and authors. 